\title{
KARAKTERISTIK KIMIA DAN ORGANOLEPTIK KERUPUK UBI JALAR (IPOMOEA BATATAS L.) DENGAN SUBTITUSI DAGING IKAN LEMADANG (CORYPHAENA SP.)
}

\author{
CHEMICAL AND ORGANOLEPTIC CHARACTERISTICS OF SWEET POTATO \\ (IPOMOEA BATATAS L.) CRACKERS USING LEMADANG FISH \\ (CORYPHAENA SP.) MEAT AS SUBSTITUTION
}

\author{
Angcivioletta Moniharapon \\ Balai Riset dan Standardisasi Industri Manado \\ Jalan Diponegoro No. 21-23 Manado 95112 \\ e-mail: moniharaponletta@yahoo.co.id
}

\begin{abstract}
ABSTRAK
Ubi jalar merupakan salah satu sumber karbohidrat. Kerupuk ubi jalar yang dibuat dalam penelitian ini akan diperkaya kandungan protein dengan penambahan daging ikan lemadang dalam adonan kerupuk. Penelitian ini bertujuan untuk mengetahui pengaruh penambahan daging ikan lemadang dengan konsentrasi yang berbeda terhadap nilai organoleptik dan karakteristik kimia kerupuk ubi jalar. Penggunaan ubi jalar dengan ikan lemadang memakai perbandingan yaitu 100:0; 99:1; 98.5:1.5; 98:2; dan 97.5:2.5. Hasil penelitian menunjukkan bahwa perbandingan pemberian daging ikan lemadang dan ubi jalar memberikan pengaruh nyata $(P<0,05)$ terhadap karakteristik kimia. Karakteristik kimia terbaik diberikan oleh perlakuan penambahan daging ikan lemadang $2.5 \%$ dengan kandungan karbohidrat $66.8 \%$, protein $20.7 \%$, lemak $3.0 \%$, air $5.0 \%$ dan abu $2.86 \%$. Uji organoleptik terbaik juga pada perlakuan penambahan daging ikan 2.5\% dengan kenampakan 6.10, bau 6.80, rasa 6.87 dan tekstur 6.67.

Kata Kunci : Ikan lemadang, kerupuk, karakteristik kimia, karakteristik organoleptik, ubi jalar.
\end{abstract}

\section{ABSTRACT}

Sweet potato is one source of carbohydrates. The sweet potato crackers made in this experiment was enriched with protein by the addition of mahi-mahi fish. The study was aimed to determine the effect of different concentration of added mahi-mahi fish on the chemical and organoleptic characteristics of sweet potato crackers. The comparison of sweet potato to mahi-mahi fish were $100: 0 ; 99: 1 ; 98.5: 1.5$; 98:2 and 97.5:2.5, respectively. The results showed that the comparison of sweet potato and mahi-mahi fish were significantly different $(P<0.05)$, on the chemical characteristic. The best chemical characteristics were obtained by the addition of $2.5 \%$ flesh fish with the content of carbohydrate, protein, fat, water and ash were $66.8 \% ; 20.7 \% ; 3.0 \% ; 5.0 \%$ and $2.86 \%$, respectively. The best of organoleptic characteristics was also reached by the $2.5 \%$ fish addition with the appearance of 6.10; odor 6,80; flavor 6.87; and texture 6.67.

Key Words : Crackers, chemical characteristics, mahi-mahi fish, organoleptic characteristics, sweet potato.

\section{PENDAHULUAN}

Ikan lemadang (Coryphaena hippurus L.) dikenal dengan nama mahimahi atau dolphin, merupakan salah satu hasil tangkapan sampingan dari beberapa aktivitas perikanan yang menggunakan alat tangkap tuna, tongkol dan cakalang. Perairan laut Sulawesi merupakan perairan yang berbatasan dengan Filipina dan memiliki potensi sumber daya ikan pelagis termasuk ikan lemadang yang cukup banyak (1). Ikan lemadang memiliki daging berwarna putih dan lembut sehingga biasanya diolah dalam bentuk fillet, steak, dan loin menjadi surimi, bakso dan sup. Ikan lemadang mengandung asam lemak 
jenuh yang rendah dan sebagai sumber vitamin B12, fosfor dan selenium. Selain itu ikan mahi-mahi juga tinggi akan protein, niasin, vitamin B6 dan selenium.

Ubi jalar adalah tanaman yang tumbuh menjalar di dalam tanah dan menghasilkan umbi. Kandungan terbesar dalam ubi jalar adalah karbohidrat, yang dapat dimanfaatkan sebagai sumber kalori. Kandungan karbohidrat ubi jalar tergolong Low Glycemix Index (LGI 54), yaitu tipe karbohidrat bila dikonsumsi tidak akan menaikkan gula darah secara drastis, sehingga ubi jalar aman bila dikonsumsi oleh penderita diabetes (2). Selain itu ubi jalar juga mengandung serat pangan tinggi yang baik bagi pencernaan (3).

Kerupuk pada dasarnya merupakan pencampuran antara pati dan air. Pati yang sering digunakan dalam pembuatan kerupuk adalah ubi kayu dan sagu. Pada penelitian ini akan digunakan ubi jalar sebagai bahan dasar pembuatan kerupuk kemudian sebagai bahan pengikat digunakan tapioka. Penambahan daging ikan lemadang dalam kerupuk ubi jalar diharapkan dapat mempengaruhi karakteristik kimia kerupuk, semakin besar konsentrasi daging ikan yang ditambahkan, maka kandungan protein akan meningkat.

Tujuan dari penelitian ini adalah untuk mengetahui pengaruh konsentrasi daging ikan lemadang terhadap karakteristik kimia dan organoleptik kerupuk ubi jalar.

\section{Bahan dan Metode}

Bahan yang digunakan antara lain ubi jalar, tapioka, garam halus, daging ikan lemadang, bawang putih, minyak goreng serta bahan untuk analisa proksimat. Alat yang dipakai di antaranya panci kukus, penggiling, pisau, roller, wajan penggorengan, kompor gas serta set peralatan untuk uji proksimat.

\section{Metode}

Penelitian ini dilakukan dengan metode deskriptif. Penggunaan ubi jalar dengan ikan memakai perbandingan. Besarnya perbandingan yaitu 100:0; 99:1; 98.5:1.5 ; 98:2; dan 97.5:2.5. Perlakuan $\mathrm{L}_{0}=$ tanpa penambahan daging ikan lemadang $0 \% ; L_{1}=$ penambahan daging ikan lemadang $1 \% ; L_{2}=$ penambahan daging ikan lemadang $1.5 \% ; L_{3}=$ penambahan daging ikan lemadang $2.0 \%$ dan $\mathrm{L}_{4}=$ penambahan daging ikan lemadang $2.5 \%$. Penambahan bumbu konstan antara lain : garam $1 \mathrm{~g}$, bawang putih $1 \mathrm{~g}$ dan tapioka $10 \mathrm{~g}$. Ubi jalar dikupas kulitnya lalu dicuci bersih dengan air mengalir. Kemudian ubi jalar diparut dan ditambahkan bumbubumbu, tapioka dan daging ikan lemadang. Penambahan daging ikan mengikuti besarnya jumlah perbandingan yaitu $0 \%$, $1 \%, 1.5 \%, 2 \%$ dan $2.5 \%$. Sehingga ada lima jenis adonan yang dipisahkan sesuai perlakuan. Kemudian masing-masing adonan dihomogenkan dan dicetak berbentuk silinder. Setelah itu dikukus selama 10-15 menit dan didinginkan. Hasil kukusan dipotong dengan ketebalan 0.1-0.2 $\mathrm{cm}$. Selanjutnya dikeringkan dalam oven pada suhu $50-55^{\circ} \mathrm{C}$ selama 48 jam. Didinginkan kemudian kerupuk ubi jalar siap digoreng. 


\section{Analisis Proksimat dan Organoleptik Kerupuk Ubi Jalar}

Analisis kimia berupa kadar karbohidrat, protein, lemak kadar air dan kadar abu mengacu pada analisa proksimat (4). Penilaian organoleptik terhadap kerupuk ikan ubi jalar didasarkan pada penilaian penampakan, bau, rasa dan tekstur. Uji organoleptik dilakukan oleh 25 panelis terhadap kerupuk ubi jalar yang sudah digoreng. Penilaian organoleptik dilakukan secara bersamaan atau dalam satu waktu pada masing-masing perlakuan berdasarkan score sheet organoletik kerupuk ikan (5). Tingkat kesukaan dengan skala hedonik selanjutnya ditransformasikan menjadi skala numerik. Skor yang digunakan dari 1 sampai 7 , dimana 1 =sangat tidak suka ; $2=$ tidak suka ; 3=Agak tidak suka ; 4=Netral; 5=Agak suka ; $6=$ Suka dan $7=$ sangat suka.

\section{HASIL DAN PEMBAHASAN}

\section{Hasil Uji Proksimat Kerupuk ubi jalar}

Uji kadar proksimat yang dilakukan pada penelitian ini meliputi kadar karbohidrat, protein, lemak, air, dan abu. Hasil uji proksimat dapat dilihat pada Tabel 1.

Tabel 1. Hasil uji proksimat kerupuk ubi jalar

\begin{tabular}{lccccc}
\hline \multirow{2}{*}{ Proksimat } & \multicolumn{4}{c}{ Perlakuan Penambahan Daging Ikan Lemadang } \\
\cline { 2 - 6 } & $\mathbf{L}_{\mathbf{0}}=\mathbf{0} \%$ & $\mathbf{L}_{\mathbf{1}}=\mathbf{1} \%$ & $\mathbf{L}_{\mathbf{2}}=\mathbf{1 . 5 \%}$ & $\mathbf{L}_{\mathbf{3}}=\mathbf{2} \%$ & $\mathbf{L}_{\mathbf{4}}=\mathbf{2 . 5} \%$ \\
\hline Karbohidrat (\%) & $87.52 \pm 0.24^{\mathrm{a}}$ & $\mathbf{7 5 . 8 5} \pm 0.40^{\mathrm{b}}$ & $72.66 \pm 0.30^{\mathrm{c}}$ & $70.15 \pm 0.88^{\mathrm{d}}$ & $66.88 \pm 0.44^{\mathrm{e}}$ \\
Protein (\%) & $2.09 \pm 0.16^{\mathrm{a}}$ & $12.88 \pm 0.30^{\mathrm{b}}$ & $15.66 \pm 0.15^{\mathrm{c}}$ & $17.97 \pm 0.51^{\mathrm{a}}$ & $20.71 \pm 0.72^{\mathrm{e}}$ \\
Lemak (\%) & $0.14 \pm 0.08^{\mathrm{a}}$ & $1.27 \pm 0.24^{\mathrm{b}}$ & $1.82 \pm 0.16^{\mathrm{c}}$ & $2.54 \pm 0.43^{\mathrm{d}}$ & $3.01 \pm 0.12^{\mathrm{e}}$ \\
Air (\%) & $8.81 \pm 0.10^{\mathrm{a}}$ & $7.36 \pm 0.34^{\mathrm{b}}$ & $6.81 \pm 0.10^{\mathrm{c}}$ & $5.91 \pm 0.21^{\mathrm{d}}$ & $5.00 \pm 0.13^{\mathrm{e}}$ \\
Abu (\%) & $0.42 \pm 0.28^{\mathrm{a}}$ & $1.54 \pm 0.15^{\mathrm{b}}$ & $2.04 \pm 0.10^{\mathrm{c}}$ & $2.41 \pm 0.13^{\mathrm{d}}$ & $2.86 \pm 0.06^{\mathrm{e}}$ \\
\hline
\end{tabular}

\section{Kadar Karbohidrat}

Hasil uji kadar karbohidrat menunjukkan terjadinya penurunan kadar karbohidrat seiring dengan penambahan daging ikan karena dengan bertambahnya konsentrasi daging ikan maka proporsi dari ubi jalar akan berkurang, sedangkan kadar karbohidrat dari ubi jalar tergolong tinggi yaitu sebesar $80.4 \%$. Tepung tapioka sendiri mempunyai kandungan karbohidrat yang cukup tinggi yaitu sekitar $86.9 \%$ (6). Karbohidrat kerupuk ikan berada diantara $59.74-73.70 \% \quad$ (9). Sedangkan kadar karbohidrat pada kerupuk komersial seperti dalam penelitian (7) berada di antara 50$80 \%$. Penambahan daging ikan lemadang memberikan beda nyata terhadap kadar karbohidrat kerupuk ikan $(\mathrm{P}<0.05)$.

\section{Kadar Protein}

Hasil uji kadar protein pada Tabel 1 menunjukkan bahwa kadar protein kerupuk ubi jalar cenderung meningkat seiring dengan penambahan konsentrasi ikan lemadang. Hal ini diduga karena karena penambahan daging ikan lemadang, di mana kadar protein ikan lebih tinggi dari kadar protein ubi jalar. Pada perlakuan kontrol, kadar protein sangat sedikit karena tanpa adanya penambahan daging ikan. Hasil penelitian ini sesuai dengan standar SNI 01-2713-2009 (5) tentang kerupuk ikan dengan kadar protein minimal $6 \%$ kecuali 
kontrol. Kandungan protein dalam penelitian ini lebih besar jika dibandingkan dengan kadar protein kerupuk komersial pada penelitian (7), kadar protein kerupuk komersial berada pada kisaran 5.5316.17\%. Pada penelitian (1), protein ikan lemadang adalah $31.45 \%$ per $170 \mathrm{~g}$ oleh karena itu terdapat perbedaan yang jauh pada perlakuan kerupuk ubi jalar yang diberi penambahan ikan lemadang dan perlakuan kontrol. Kandungan protein pada kontrol diperoleh dari ubi jalar dan tepung tapioka. Perlakuan penambahan daging ikan dengan konsentrasi yang berbeda menyebabkan nilai rata-rata protein produk kerupuk ikan menyebabkan perbedaan yang nyata $(P<0.05)$.

\section{Kadar Lemak}

Hasil uji kadar lemak pada Tabel 1 menunjukkan bahwa kadar lemak cenderung meningkat seiring dengan penambahan konsentrasi daging ikan lemadang. Kandungan lemak dari ikan lemadang lebih besar dari ubi jalar sehingga penambahan daging ikan berpengaruh terhadap kadar lemak kerupuk. Kontrol mengandung kadar lemak paling kecil karena tanpa adanya penambahan daging ikan dalam pembuatan kerupuk ubi jalar. (1), kandungan lemak dari ikan lemadang sebesar 0.2-5.0\%, ditambahkan kadar lemak dari tepung tapioka yang sebesar $0.5 \%$. Menurut (8) pengaruh penambahan daging ikan ke dalam pengolahan produk kerupuk ikan dapat menambahkan lemak produk tersebut. Kadar lemak pada semua perlakuan tidak memenuhi standar mutu lemak menurut (5), yaitu kadar lemak maksimal $0,5 \%$. Hasil analisis menunjukkan perlakuan penambahan konsentrasi daging ikan berbeda nyata $(P<0.05)$ terhadap nilai lemak kerupuk ubi jalar.

\section{Kadar Air}

Hasil uji kadar air kerupuk ubi jalar pada Tabel 1 menunjukkan bahwa kadar air cenderung menurun seiring dengan penambahan konsentrasi daging ikan lemadang. Kontrol mendapatkan nilai kadar air paling tinggi karena tidak ada penambahan daging ikan dengan demikian persentase ubi jalar lebih besar. Pati ubi jalar akan mengikat air pada waktu gelatinisasi, semakin besar persentase pati ubi jalar dalam kerupuk maka kadar airnya akan semakin besar (9). Kadar air kerupuk komersial berada di antara 9.37-13.83\% (7), didukung juga kadar air maksimal kerupuk dalam SNI 01-2713-2009 adalah $13 \%$ (5). Hasil analisa kandungan air mengalami penurunan sejalan dengan penambahan protein, abu dan lemak, karena selama proses pengeringan molekul-molekul air yang terikat akan dilepaskan oleh protein (10). Perlakuan penambahan konsentrasi daging ikan berbeda nyata $(\mathrm{P}<0.05)$ terhadap kadar air kerupuk ubi jalar.

\section{Kadar Abu}

Hasil uji kadar abu pada Tabel 1 menunjukkan bahwa kadar abu pada kerupuk ubi jalar cenderung meningkat. Hal ini disebabkan karena penambahan daging ikan lemadang pada kerupuk. Ikan yang ditambahkan merupakan bahan pangan hewani yang tinggi kadar abunya, hal ini disebabkan karena kandungan sejumlah 
mineral yang terkandung di dalamnya seperti kalsium, besi dan fosfat. Kontrol mengandung kadar abu paling rendah karena dalam pembuatan kerupuk tanpa ditambahkan daging ikan (11) menyatakan bahwa konsentrasi kadar abu pada kerupuk ikan meningkat sejalan penambahan daging ikan. Selanjutnya dikatakan bahwa jenis ikan yang ditambahkan dalam kerupuk ikan menyebabkan perbedaan dalam kadar abu, dan semakin banyak kandungan ikan dalam kerupuk ikan maka kandungan kadar abu semakin meningkat. Sedangkan kadar abu kerupuk komersial menurut (7) berkisar antara $3.39 \%$ sampai $5.94 \%$. Maka perlakuan penambahan daging ikan dengan konsentrasi yang berbeda menyebabkan perbedaan yang nyata $(P<0.05)$.

\section{Organoleptik}

Penilaian organoleptik terhadap kerupuk ubi jalar didasarkan pada penilaian penampakan, bau, rasa dan tekstur. Hasil uji organoleptik tersaji pada Tabel 2.

\section{Kenampakan}

Pada Tabel 2 terlihat bahwa bahwa penambahan ikan lemadang pada kerupuk ubi jalar tidak mempengaruhi nilai organoleptik pada kenampakannya. Secara garis besar kenampakan pada kerupuk ubi jalar menunjukkan hasil yaitu utuh, rapi, ketebalan tidak rata, warna coklat keputihan. Hasil uji Kruskal Wallis menunjukkan bahwa perlakuan penambahan daging ikan lemadang pada pembuatan kerupuk ubi jalar tidak memberikan pengaruh perbedaan nyata $(P>0.05)$. Hasil ini didukung oleh (12) bahwa penambahan limbah udang dengan konsentrasi yang berbeda dalam pembuatan kerupuk ikan tidak mempengaruhi nilai organoleptik kenampakan.

\section{Bau}

Pada Tabel 2 terlihat bahwa kontrol $L_{0}$ mendapatkan nilai yang rendah karena tanpa adanya penambahan daging ikan dalam pembuatan kerupuk ubi jalar, sehingga tidak terdapat aroma ikan dalam kerupuk tersebut. Hasil ini menunjukkan bahwa penambahan daging ikan dengan konsentrasi yang berbeda mempengaruhi bau atau aroma kerupuk ubi jalar, semakin banyak konsentrasi daging ikan yang ditambahkan dalam adonan kerupuk maka kadar aroma dalam kerupuk tersebut akan meningkat. Hasil uji Kruskal Wallis menunjukkan bahwa nilai bau pada kelima perlakuan masing-masing memberikan pengaruh perbedaan nyata $(P<0.05)$ terhadap kerupuk ubi jalar. Hasil uji lanjut Dunn's Multiple Comparison yaitu terdapat perbedaan nyata $(\mathrm{P}<0.05)$ pada semua perlakuan. Hasil ini sesuai dengan (12) yang mendapatkan perbedaan yang nyata pada penambahan limbah kepala udang dalam pembuatan kerupuk udang. Semakin banyak konsentrasi limbah kepala udang yang ditambahkan dalam pembuatan kerupuk, maka aroma udang akan semakin kuat.

\section{Rasa}

Pada Tabel 2 terlihat bahwa nilai rata-rata rasa pada kontrol $\mathrm{L}_{0}$ rendah disebabkan tanpa adanya penambahan daging ikan, sehingga rasa ikan tidak ada. 
Hasil ini menunjukkan dengan penambahan daging ikan yang semakin banyak dalam pembuatan kerupuk ubi jalar, maka rasa ikan yang terkandung dalam kerupuk akan semakin kuat. Hasil uji Kruskal Wallis menunjukkan bahwa nilai rasa pada kelima perlakuan masing-masing memberikan pengaruh perbedaan nyata $(\mathrm{P}<0.05)$ terhadap nilai rasa kerupuk ubi jalar. Hasil uji lanjut Dunn's Multiple Comparison yaitu terdapat perbedaan nyata pada semua perlakuan. Komponen pembentuk rasa bahan pangan berhubungan dengan protein dalam bahan pangan, semakin banyak protein yang terkandung maka produk yang dihasilkan akan terasa semakin gurih (13).

\section{Tekstur}

Pada Tabel 2 terlihat bahwa penambahan daging ikan memberikan nilai tekstur yang berbeda. Perbedaan penambahan limbah udang dalam pembuatan kerupuk menghasilkan nilai tekstur yang berbeda (12). Hasil uji Kruskal Wallis menunjukkan bahwa perlakuan memberikan pengaruh perbedaan nyata $(\mathrm{P}<0.05)$ terhadap nilai tekstur produk kerupuk ubi jalar. Hasil uji lanjut Dunn's Multiple Comparison yaitu terdapat perbedaan yang nyata pada perlakuan $\mathrm{L}_{0^{-}}$ $\mathrm{L}_{4}$. Hal ini sesuai dengan pendapat (14), yaitu olahan ikan yang mengandung tepung, saat pemanasan akan terjadi proses gelatinisasi di mana granula pati menyerap air dan terjadi pembengkakan. Selanjutnya granula ini akan pecah sehingga air yang masuk dalam butir-butir pati tidak dapat bergerak bebas. Hal ini berakibat pada tekstur produk menjadi padat dan kompak.

Tabel 2. Hasil uji organoleptik kerupuk ubi jalar

\begin{tabular}{lccccc}
\hline \multirow{2}{*}{ Spesifikasi } & \multicolumn{5}{c}{ Perlakuan Penambahan Daging Ikan Lemadang } \\
\cline { 2 - 6 } & $\mathbf{L}_{\mathbf{0}}=\mathbf{0} \%$ & $\mathrm{~L}_{\mathbf{1}}=\mathbf{1} \%$ & $\mathrm{~L}_{\mathbf{2}}=\mathbf{1 . 5 \%}$ & $\mathbf{L}_{\mathbf{3}}=\mathbf{2} \%$ & $\mathbf{L}_{\mathbf{4}}=\mathbf{2 . 5 \%}$ \\
\hline Kenampakan & $6.10 \pm 0.31^{\mathrm{a}}$ & $6.13 \pm 0.35^{\mathrm{b}}$ & $6.17 \pm 0.38^{\mathrm{C}}$ & $6.13 \pm 0.35^{\mathrm{d}}$ & $6.10 \pm 0.48^{\mathrm{e}}$ \\
Bau & $4.77 \pm 0.77^{\mathrm{a}}$ & $6.27 \pm 0.45^{\mathrm{b}}$ & $6.43 \pm 0.50^{\mathrm{C}}$ & $6.57 \pm 0.50^{\mathrm{d}}$ & $6.80 \pm 0.41^{\mathrm{e}}$ \\
Rasa & $4.33 \pm 0.48^{\mathrm{a}}$ & $6.47 \pm 0.51^{\mathrm{b}}$ & $6.57 \pm 0.50^{\mathrm{C}}$ & $6.73 \pm 0.52^{\mathrm{d}}$ & $6.87 \pm 0.43^{\mathrm{e}}$ \\
Tekstur & $6.00 \pm 1.29^{\mathrm{a}}$ & $6.40 \pm 1.33^{\mathrm{b}}$ & $6.47 \pm 1.36^{\mathrm{c}}$ & $6.53 \pm 1.48^{\mathrm{d}}$ & $6.67 \pm 1.09^{\mathrm{e}}$ \\
\hline
\end{tabular}

\section{KESIMPULAN DAN SARAN}

$$
\begin{array}{rr}
\text { Penambahan daging ikan } \\
\text { lemadang dapat mempengaruhi }
\end{array}
$$

karakteristik kimia dan oragnoleptik kerupuk ubi jalar. Karakteristik kimia dan organoleptik terbaik diberikan oleh perlakuan penambahan daging ikan lemadang $2.5 \%$. Dengan kandungan karbohidrat $66.8 \%$, protein $20.7 \%$, lemak $3.0 \%$, air $5.0 \%$ dan abu $2.86 \%$, serta kenampakan 6.10 , bau 6.80 , rasa 6.87 dan tekstur 6.67. Perlu adanya penelitian lanjutan tentang daya simpan produk kerupuk ubi jalar dan jenis kemasannya.

\section{DAFTAR PUSTAKA}

1. Chodrijah, $U$ dan Nugroho D. Struktur ukuran dan parameter populasi ikan lemadang (Coryphaena hippurus Linnaeus, 1758) di laut Sulawesi. Bawal 8(3) hal.147158. 2016.

2. Ekawati, G, Hapsari AL, dan Wipranyawati, $P$. Kajian varietas nan bagian daging ubi ungu dalam rangka penyediaan tepung Ubi ungu sehat termodifikasi. J Lit IImu dan TekPan Universitas Udayana Denpasar. 2013.

3. Murtiningsih dan Suryanti. Membuat Tepung Umbi dan Variasi Olahannya. PT. Agromedia Pustaka. Jakarta. 2011. 
4. Association of Official Analytical Chemist (AOAC). Official Methods of Analysis of The Association of Official Analytical Chemist. Washington DC. 2006.

5. Badan Standardisasi Nasional (BSN). SNI Kerupuk Ikan No. 01-2713-2009. Jakarta. 2009.

6. Prasetya, HA.. Penggunaan tepung ubi jalar (Ipomoea batatas L.) pada pembuatan. 2011.

7. Huda N., Ang L. L., Chung $X, Y$ and Herpandi. Chemical composition, colour and linear expansion properties of Malaysian commercial fish cracker (Keropok). Asian Journal of Food and Agro-Industry 3(5), 473-482. 2010.

8. Kurniawati, CP. Kualitas kerupuk kombinasi ikan gabus (Channa striata Bloch), tepung ubi jalar (Ipomoea batatas L) Putih dan Tepung Tapioka. Jurnal Teknobiologi Vol. 1 No.5. 2013.

9. Andarwulan, N., F. Kusnandar dan D. Herawati, Analisis Pangan. Dian Rakyat. Jakarta. 2011.
10. Afrila, A dan Budi, S. Water Holding Capacity (WHC), Kadar Protein dan Kadar air Dendeng Sapi pada Berbagai Konsentrasi Ekstrak Jahe (Zingiber officinale Roscoe) dan Lama Perendaman yang Berbeda. Jurnal IImu dan Teknologi Hasil Ternak Vol. 6. No.2 . ISSN : 19780303. 2011.

11. Huda N., Boni, I., Noryati, I. The effect of different ratios of dory fish on tapioca the linier expansion, oil absortion, colour and hardness of fish crackers. International Food RTecsearch Journal 16 : 159-165. 2009.

12. Firlianty. Pemanfaatan limbah udang (Penaeus sp) sebagai alternative bahan pengolahan kerupuk untuk mengurangi resiko pencemaran lingkungan. Journal of Tropical Fisheries 4(2):450-458. 2009.

13. Aryani N. Pengaruh konsentrasi putih telur ayam ras terhadap kemekaran kerupuk ikan mas (Cyprinus carpio). Journal of Tropical Fisheries. Vol.VI : No. 2. 2011.

14. Winarno, F.G., 2002. Kimia Pangan dan Gizi. Gramedia. Jakarta. 
